Acta Biologica Plantarum Agriensis 5(1): 51 (2017) ISSN 2061-6716 (Print), 2063-6725 (Online) http://abpa.ektf.hu/
DOI:10.21406/abpa.2017.5.1.51

$4^{\text {th }}$ CC 2017 Abstract Poster

\title{
Distribution OF THE GENUS TRAPELIOPSIS HERTEL \& GOTTH. SCHNEID. (LICHENISED ASCOMYCOTA) IN HUNGARY
}

A Trapeliopsis Hertel \& Gotth. Schneid. zuzmónemzetség magyarországi elterjedése

\section{Dániel Kovács ${ }^{1}$, Gábor MATUS², Mónika SINIGLA ${ }^{3}$ László LőKÖS ${ }^{4}$}

\begin{abstract}
${ }^{1} \mathrm{H}-2422$ Mezőfalva, Fehérvári út 41, Hungary; ${ }^{2}$ Department of Botany, University of Debrecen; H-4010 Debrecen, Egyetem tér 1, Hungary; ${ }^{3}$ Bakony Museum of the Hungarian Natural History Museum; H-8420 Zirc, Rákóczi tér 3-5, Hungary; ${ }^{4}$ Department of Botany, Hungarian Natural History Museum; H-1097 Budapest, Könyves Kálmán körút 40, Hungary; e-mail: dancs12@msn.com
\end{abstract}

All Trapeliopsis species found in Hungary have crustose, thin, granular or minutely squamulose, greyish, greenish-grey or yellowish-green thallus covered frequently by dense soralia. Apothecia if present are sessile, adpressed, round, the discus yellowish-brown, pinkish to dark grey up to black. They usually grow on siliceous rocks, acidic soil, decaying plant debris, decaying hardwood or on rotten wood. Although most Trapeliopsis species are cosmopolitan, little information was available on their presence and distribution in Hungary.

Hungarian occurrences of three Trapeliopsis species were accepted in Klára Verseghy's "Lichen flora of Hungary" in 1994, i.e. T. flexuosa (Fr.) Coppins \& P. James (as Lecidea aeruginosa) from the Mátra and Pilis Mts; T. granulosa (Hoffm.) Lumbsch (as Lecidea granulosa) from the Zemplén, the Bükk and the Bakony Mts; as well as T. viridescens (Schrad.) Coppins \& P. James (as Lecidea viridescens) from the Bükk Mts. According to the available specimens and literature records of that time, all three species were regarded by her as very rare species in Hungary. As a result of our revision of the two specimens of T. viridescens cited in Verseghy's flora work this species turned to be T. flexuosa. Due to the extensive lichenological exploration in the last decades several new floristical records of $T$. flexuosa and $T$. granulosa were registered from various areas of Hungary, which support our idea that both cosmopolitan species are also frequent and widely distributed in Hungary. Our recent investigations also confirm the occurrence of T. gelatinosa (Flörke) Coppins \& P. James from the Mecsek Mts, which had only one former specimen collected in the Bükk Mts in 1939, still waiting for revision. T. pseudogranulosa Coppins \& P. James, another common lichen species worldwide, was discovered recently in Hungary from the Karancs, Mátra, Mecsek and Pilis Mts. Further occurrences of the two latter species are expected in Hungary from suitable habitats, i.e. from bare acidic soil.

Our investigations were partly supported by the grant NKFI K 124341. 